\title{
Women's Response Methods to the Consequences of Climate Change - A Survey Study in Dubti, Afar, Ethiopia
}

\author{
Biniam Debela(MA in Gender and Development) \\ Lecturer, Department of Civic and Ethical Studies, Raya University, P.O. Box 92, Maichew, Ethiopia. \\ Mebrahtom Guesh (MA in Development Studies) \\ Lecturer, Department of Civic and Ethical Studies, Raya University, P.O. Box 92, Maichew, Ethiopia.
}

\begin{abstract}
The majority Ethiopian women are largely engaged in the agricultural sector, which is highly vulnerable to climate changes. This study, aims at analyzing the determinants of women's response measures of climate change in the Dubti Woreda. This article designed as a cross-sectional research design and employed qualitative and quantitative research approaches. Data was obtained from primary and secondary sources. Moreover, both the probability and non probability sampling techniques were employed. Accordingly, this article found that five major response mechanism to the consequence of climate change. The result from the binary logistic model reveals that age, access to training, farming experience, access to credit service, radio and mobile services determines women's response methods to the consequence of climate changes. Finally, the article recommends for greater investment in women education and training to address the above mentioned challenges.
\end{abstract}

Keywords: Climate change, Response Strategy, Binary Logistic Regression Model.

DOI: $10.7176 / \mathrm{JCSD} / 47-03$

Publication date: April $30^{\text {th }} 2019$

\section{INTRODUCTION}

\section{Background of the Study}

The impact of climate change is increasing from time to time. Climate change causes for floods, droughts, cyclones and desertification processes and this put the population of the world, especially developing countries at high risk and can undermine the development efforts to reduce poverty (Anne, 2009).

The poor are the most vulnerable to climate change and women are among the greatest number share of the poor, because women constitute more than $70 \%$ of the overall worldwide population living below the poverty line, and this implies how many women are more vulnerable to the effects of climate change compared to other groups (Ulrike, 2006).

Societies have a long evidence of adapting to the consequence of climate change through different sorts of practice, such as crop diversification, irrigation, water management, disaster risk management, and insurance, but climate change adversely attacks these coping mechanisms due to drought, heat waves and hurricane intensity (Adger, et al., 2007).

Nhemachena and Hassan (2007) identified the important determinants of response to climate change in South Africa, Zambia and Zimbabwe to be access to credit and extension, and also women's consciousness about climate change, as such, that the study suggested enhancing access to credit and information about climate and agronomy so as to boost women's response to the consequence of climate change.

Ethiopia's overall vulnerability to climate change was ranked 10th of 233 countries (Center for Global Development (CGD), 2012) and climate change are considered a significant threat to the development of the country (ACCRA, 2011). As a result, Ethiopia's development and growth potential have been held back by climate variability, uncertainty and change (Dinku et al., 2011).

To this end, the article deems that, the present Ethiopian government has been drafting policies and strategies and applying a lot of response mechanisms to tackle the impact of climate change. However, the policies and strategies and these response mechanisms are not gender sensitive which means does not recognize the role of women in the environmental protection process.

\section{Statement of the Problem}

Climate change has gender-specific implications in terms of response and there are structural differences between men and women through, for example, gender-specific roles in society, work and domestic life (Cutter, 1995; Denton, 2002; Enarson, 2002). These differences affect the decision of women to give response to the consequence of climate change (Dankelman, 2002).

Response strategies are uneven across and within societies. In relation to this, there are individuals and groups within all societies that have an insufficient decision to response of climate change, for example, in most African countries women in subsistence farming communities are disproportionately burdened with the costs of recovery and coping with drought (Adger, et al., 2007). 
The decision to response is dynamic and influenced by economic and natural resources, social networks, entitlements, institutions and governance, human resources, and technology (Ibid).

Furthermore, women in Sub-Saharan Africa have lower levels of education; they have smaller farms, less access to markets, credit and other inputs which also might be a factor limiting their response strategies to the consequence of climate change (Blackden and Wodon, 2006).

In recent times, a significant number of people in Ethiopia are being affected chronically by drought and/or flooding, leading to the deaths of people and loss of assets and this problem is very serious in the arid and semiarid areas (Yohannes \& Mebratu, 2009).

According the data of the Woreda Dubti is one of the arid and partially drought affected areas. As a result, the livelihoods of several women are endangered and limited their decisions to employ response strategies to climate change due to lack of rainfall and other climatic change problem. Though, there is insufficient of empirical analysis carried out to elucidate the specific factors that influence women's decision to adopt response strategies to climate change. Therefore, the general objective of this article is to examine the determinant factors of women's response strategies to climate change in Dubti Woreda, Ethiopia. More specifically, this article has two research questions:

- What are the existing women response strategies to the consequence of climate change?

- What are the factors that affect women response strategies to the consequence of climate change?

\section{RESEARCH METHODOLOGY}

\section{Description of the Study Area}

Dubti is one of the Woredas in the Afar Region of Ethiopia. Part of the Administrative Zone 1, Dubti is bordered on the south by the Somali Region, on the southwest by Mille, on the west by Chifra, on the northwest by the Administrative Zone 4, on the north by Kori, on the northeast by Elidar, on the east by Asayita, and on the southeast by Afambo. Towns in Dubti include $\underline{\text { Dubti, Logiya, and Semera. }}$

The average elevation in this woreda is 503 meters above sea level; the highest point in Dubti is Mount Manda Hararo 600 meters (Hailu Ejara, 2008). Rivers include the Awash River, which splits the Woreda into northern and southern parts, and its tributary the Logiya. Alongside the Awash are the Dubti Marshes, which cover an area 34 by 12 kilometers, and whose dominant vegetation is Phragmites (Robert Mepham, R. H. Hughes, and J. S. Hughes, 1992). These marshes are under encroachment by the Tendaho Cotton Plantation, whose fields surround the town of Dubti. As of 2008, Dubti has 314 kilometers of all-weather gravel road; about $22.33 \%$ of the total population has access to drinking water (Hailu Ejara, 2008).

Based on the 2007 national census conducted by the Central Statistical Agency of Ethiopia (CSA), this Woreda has a total population of 65,342, of whom 34,893 are men and 30,449 women; 32,940 or $50.41 \%$ are urban inhabitants; $88.01 \%$ of the population were Muslim, and $11.46 \%$ were Orthodox Christians (Afar Census, 2007). A sample enumeration performed by the CSA in 2001 interviewed 1676 farmers in this woreda, who held an average of 0.72 hectares of land. Of the 1.21 square kilometers of private land surveyed, $28.15 \%$ were under cultivation, $64.53 \%$ fallow, 3.46\% was devoted to other uses (AgSE, 2007). For the land under cultivation in this woreda, $27.9 \%$ in planted in cereals like maize; none of the land was planted in pulses and vegetables. All of the farmers reporting only raised livestock. For land tenure in this woreda, 94\% own their land; (Ibid).

\section{Figure 1: Location of Dubti Woreda, Afar}

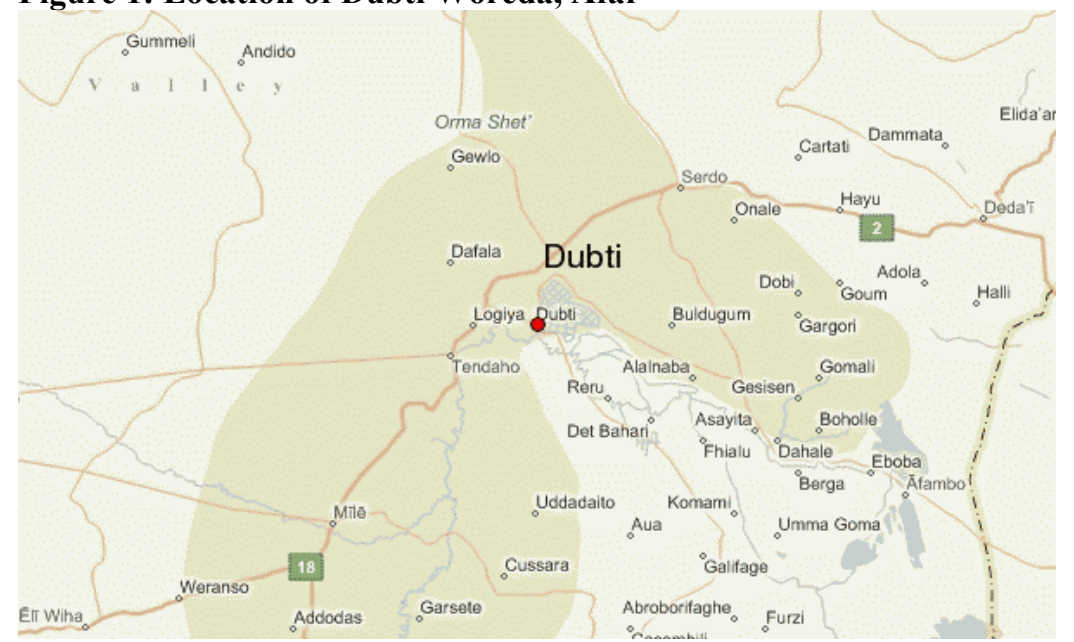

Source: Dubti weather forecast.com, (2017) 


\section{Research Design}

This article designed as a cross-sectional research design and survey study. This is because the cross-sectional research design allows data to be collected at one point in time (Mbwambo, 2007). The design also has a greater degree of accuracy in social science studies than other design (Casley and Kumar, 1998).

\section{Research Approach}

This article employed qualitative and quantitative research approaches. Qualitative approaches to research are concerned with the subjective assessment of attitudes, opinion and behaviour while quantitative research is based on the measurement of quantity or amount which is applicable to phenomena that can be expressed in terms of quantity (Kothari, 2004).

\section{Data Types and Sources}

As a way to collect a reliable and relevant data the researcher has employed both primary and secondary sources of data. Accordingly, primary data were collected from women residing in Dubti Woreda and from Kebelle chairpersons as the main source of data. Moreover, the article has also employed secondary sources of data in order to triangulate the primary data analysis.

\section{Sampling Techniques}

There are 3 Kebelles in Dubti Woreda. Therefore, the researcher selected two Kebelles by employing a nonprobability sampling particularly a purposive sampling. The main reason for the researcher to select the two Kebelles is the degree of vulnerability to climate change, drought and the presence of a large number of women. The women who are living in the selected Kebelles are the target population of the article and for particular selection the article employed a probability sampling design. More specifically, the article employed systematic random sampling. Wherein, the researcher initially obtained the whole list of women from the Woreda administration and then selected the samples using the $\mathrm{n}^{\text {th }}$ interval, in which the first unit of the sample selected at random and the subsequent units are selected in a systematic way.

For the selection of key informants a judgmental (non-probability) sampling method was employed. In this regard, the specific individuals considered as key informants in the study were selected by the researcher because the researcher believes that these informants are well experienced and can give detailed information.

Regarding the quantitative data collection, the article employed the formula provided by Yamane (1967) as simplified formula to calculate sample sizes and to minimize sampling error. This formula considers a $95 \%$ confidence level and $\pm 8 \%$ precision to calculate the sample size.

$$
\mathrm{n}=\frac{\mathrm{N}}{1+\mathrm{N}(\mathrm{e})^{2}}
$$

Where:

$\mathrm{n}=$ is the sample size,

$\mathrm{N}=$ is the population size, and

$\mathrm{e}=$ is the level of precision.

$$
\begin{aligned}
& \mathrm{n}=\frac{224}{1+224(0.08)^{2}} \\
& \mathrm{n}=\frac{224}{1+224(0.0064)}
\end{aligned}
$$$$
\mathrm{n}=\underline{\mathbf{9 2}}
$$

Therefore, the 92 women were the sample size of this article. Hence, the article used the proportional allocation of respondents for each selected Kebelles.

\section{Table 1. Sampled Kebelles, Number of women and Sample Size}

\begin{tabular}{|l|l|l|l|}
\hline Number & Name of Kebelles & Number of women & Number of sample respondents \\
\hline 1 & 01 & 130 & 53 \\
\hline 2 & 03 & 94 & 39 \\
\hline \multicolumn{2}{|r|}{ Total } & 224 & 92 \\
\hline
\end{tabular}

Source: Own Survey, 2017 


\section{Data Collection Instruments}

There are several ways of collecting appropriate data which differ considerably in the context of money costs, time and other resources at the disposal of the researcher Kothari (2004). Accordingly, the article has employed structured questionnaire, key informant interviews and focus group discussion (Conducted with two groups and consists 7 members in each group) as data collection methods.

\section{Methods of Data processing and Analysis}

Generally speaking, descriptive statistics and econometric model were used to analyze the collected data.

\section{Descriptive statistics}

In analyzing the data, the article employed both qualitative and quantitative data analysis techniques. The collected data through various sources were analyzed systematically in order to increase their reliability, credibility and validity. As a result, the qualitative data were analyzed by making use of descriptions, interpretations and more importantly by making summarization of the data. The quantitative data were also analyzed by using descriptive statistical tools such as (the percentages, table and bar graph) to characterize various response measures being adopted by women and Statistical Package for Social Science (SPSS) version 20.0 was also employed as the tool of analysis.

\section{Econometric Model}

An econometric model was used to identify the major response determinant factors to climate change. The assumption behind the econometric model is that women's decision on adopting of any response strategies is influenced by a variety of socioeconomic factors. Models normally used for examining relationships between qualitative dependent variables and mixed independent variables are qualitative response regression models. In this regard, linear probability, logit and probit models are the possible alternatives. Linear probability model (LPM), however, it has a number of shortcomings. For such reasons, the linear model is becoming less frequently used except as a basis for comparison to some other more appropriate models (Green, 2003). Logistic models guarantee the estimated probability increases and never cross the range of 0 to 1 , and are the most commonly and widely applied qualitative response models. Therefore, Linear Probability Model (LPM) and probit models were rejected in favour of a logit model formulation (Gujarati, 2003).

In addition, under such kind of condition and binary logistic regression model would be preferred to binary probit regression since its coefficients are comparatively simple to interpret and this would be important to analyze the effect of the predictor variables on the predicted variable.

Because of the nature of the study, women were not provided with different response options for a single or rank choice, rather they were asked with open-ended questions, to report response strategy(s) they employed in 2009 E.C in response to the consequence of climate change. The researcher found out that numerous response methods adopted simultaneously by a single respondent.

\section{Specification of Binary Logistic Model}

A binary logistic model specification is employed to model climate change response strategies of women involving dummy dependent variables with binary choices. According to Gujarati (2003), the logistic distribution function for the decision on adopting of response measures to climate change can be stated as:

$\mathrm{Pi}=\left(\frac{1}{1+\varepsilon-F(i)}\right)$

Where $\mathrm{P}$ (i) is a probability of deciding to adopt an response strategies for $\mathrm{i}^{\text {th }}$ women and $\mathrm{Z}$ (i) is a function of $\mathrm{M}$ explanatory variables $(\mathrm{Xi})$ and $\mathrm{Z}(\mathrm{i})$ is expressed as;

$Z(i)=B_{0}+B_{1} X_{1}+B_{2} X_{2}+\ldots \ldots \ldots \ldots \ldots \ldots \ldots \ldots \ldots \ldots \ldots \ldots+B_{m} X m \ldots \ldots$

Where, $\mathrm{B}_{0}$ is the intercept and $\mathrm{B}_{\mathrm{i}}$ are the slope parameter in the intercept model

But $\left(1-P_{i}\right)=\left(\frac{1}{1+\theta-z(i)}\right)$

Therefore, $\left(\frac{P i}{1-P i)}\right)=\left(\frac{1+e^{x(i)}}{1+e^{-z(i)}}\right)=e^{Z i}$ 


$$
\left(\frac{P i}{1-P i)}\right)=\left(\frac{1+e^{z(i)}}{1+e^{-I(i)}}\right)=e^{Z i}=e^{\beta 0}+\Sigma_{i}^{m}=1 \beta_{\mathrm{i}} Y_{\mathrm{i}}
$$

Taking the natural logarithms of the odds ratio of the equation (5) will result in what is called the logistic model as indicated below.

$$
\operatorname{In}\left(\frac{P i}{1-P i}\right)=\operatorname{In}\left(e^{\beta 0}+\Sigma_{i}^{m}=1 \beta_{\mathrm{i}} \mathrm{Y}_{\mathrm{i}}\right)=\mathrm{Z}
$$

If the disturbance term $\mathrm{U}_{\mathrm{i}}$ is taken into account the logistic model becomes;

$$
Z_{i}=\beta_{0}+\sum \beta i X i+U j
$$

As a result, the specification of the model is described below:

$P_{i}=F\left(Y_{i}\right)=F\left[\beta_{0}+\sum_{i=1}^{n} \beta_{i} X_{i}\right]=\left[\frac{1}{1+e^{-\left(\beta_{0}+\sum \beta_{i} X_{i}\right)}}\right]=\left[\frac{e^{Y i}}{1+e^{Y i}}\right]$

Where: $P_{i}=$ the probability $i^{\text {th }}, X_{i}$ variables

$\mathrm{F}=$ the cumulative distribution function [

$\mathrm{X}_{\mathrm{i}}=$ the predictor variables, $\mathrm{i}=1,2,3 \ldots \mathrm{n}$

$\mathrm{Y}_{\mathrm{i}}=\mathrm{a}$ linear function of $\mathrm{n}$ predictor variables $\left(\beta_{0}+\beta_{\mathrm{i}} \mathrm{X}_{\mathrm{i}}\right)$

$\mathrm{e}=$ the base of natural logarithms $(\mathrm{e}=2.718)$

$\beta_{0}$ and $\beta_{\mathrm{i}}$ are regression parameters will be estimated, where $\beta_{0}$ is an intercept and $\beta_{\mathrm{i}}$ are the slope coefficients of the predictor variables.

\section{Description of the Model Variables for Binary Logistic Model}

The dependent variable of the model: response strategy is a dependent dummy-variable in the data. The dummy was determined by assigning a value of 1 for women who indicated that they had adopted response measures to climate change and a value of 0 for women who indicated they did not adopt any response measures at all to climate change. For example, if a woman adopted at least one coping strategy to adopt climate change, then that woman is considered to have "adapted" (1). During the enumeration of the survey, respondents were presented with a scripted explanation of practices and behaviours vis-à-vis climate change response strategies, then presented with a simple dichotomy ("yes/no" response) question about whether or not they had adopted any of these behaviours due to changing climate in the region, making results here self-reported.

The explanatory/ independent variables: The independent variables that are hypothesised to affect the women adopted of response strategies are combined effects of various factors such as household characteristics, socioeconomic characteristics and institutional characteristics in which women operate. Based on the review of adopting and response strategy literature, and past research findings 15 potential explanatory variables were considered in this article and examined for their effect in women's adopting of response measures to climate change. The explanatory variables included in the analysis and the hypotheses for each explanatory variable are presented below: 
Table2. Explanatory variables included in the analysis

\begin{tabular}{|c|c|c|c|}
\hline Variables & Variable type and Description & Valued in/as & $\begin{array}{l}\text { Expected } \\
\text { Sign }\end{array}$ \\
\hline $\begin{array}{l}\text { 2. Education level of the } \\
\text { household heads (EDLEVH) } \\
\text { 3. Family size (FAMSI) } \\
\text { 4. Access to radio or mobile } \\
\text { (ACCRMOB) } \\
\text { 5. On farm income } \\
\text { (ONFARMI) } \\
\text { 6. Access to training } \\
\text { (ACCSTRA) } \\
\text { 7. Saving money } \\
\text { (SAVMONY) } \\
\text { 8. Farm size (FARMSZ) } \\
\text { 9. Farming experience } \\
\text { (FARMEXP) } \\
\text { 10. Access to credit service } \\
\text { (ACCRDS) } \\
\text { 11. Distance to main market } \\
\text { (DISMMAR) } \\
\text { 12. Access to ox plough } \\
\text { (ACCOXP) } \\
\text { 13. Livestock ownership } \\
\text { (LIVOWNP) } \\
\text { 14. Access to formal/informal } \\
\text { groups (ACCFIG) } \\
\text { making (ACCDECM) } \\
\text { (5articipation in decision } \\
\text { (A) }\end{array}$ & $\begin{array}{l}\text { Continuous, Age of the woman in } \\
\text { years } \\
\text { Categorical, number of years of } \\
\text { formal schooling attained by the } \\
\text { head of the household: } \\
\text { Continuous, number of family } \\
\text { Dummy, if the woman has an } \\
\text { access to radio or mobile } \\
\text { Continuous, Generating income } \\
\text { from on farm activity } \\
\text { Dummy, obtained training by the } \\
\text { woman } \\
\text { Dummy, saving money by the } \\
\text { woman Continuous, size of farm } \\
\text { owned by the woman } \\
\text { Continuous, number of years of } \\
\text { farming experience for the } \\
\text { woman: } \\
\text { Dummy, if a woman is a } \\
\text { costumer to credit service from } \\
\text { any source. } \\
\text { Continuous, distance between a } \\
\text { woman's house and the nearest } \\
\text { market. } \\
\text { Dummy, if the woman has an } \\
\text { access to Ox plough. } \\
\text { Continuous, number of livestock } \\
\text { possessed by the woman } \\
\text { Dummy, if the woman has an } \\
\text { access to radio/mobile. } \\
\text { Dummy, if the woman } \\
\text { decision making processes. } \\
\text { aricipated in climate related } \\
\text { a }\end{array}$ & $\begin{array}{l}1=\text { Yes, } 0=\text { otherwise } \\
1=\text { Yes, } 0=\text { otherwise } \\
\text { Years } \\
1=\text { Yes, } 0=\text { otherwise } \\
\text { Kilometers } \\
1=\text { Yes, } 0=\text { otherwise } \\
\text { Number } \\
1=\text { Yes, } 0=\text { otherwise }\end{array}$ & $\begin{array}{l}\begin{array}{l}\text { Cannot be } \\
\text { signed priori }(+ \\
\text { or }-)\end{array} \\
\text { Positive }(+) \\
\text { Positive (+) } \\
\text { Positive (+) } \\
\text { Positive (+) } \\
\text { Positive }(+) \\
\text { Positive }(+) \\
\text { Positive }(+) \\
\text { Positive }(+) \\
\text { Positive }(+)\end{array}$ \\
\hline
\end{tabular}

\section{RESULTS AND DISCUSSIONS}

\section{Existing Response Strategies of Climate Changes}

The poor women can employ different response methods to climate change by changing planting dates; diversifying crops, practicing soil and water conservation measures, planting trees and etc, and this can be possible if government provides them with the necessary support (Gbetibouo, 2009; and Yesuf et al., 2008).

This article was found the respondents employed various response strategies to climate change effects. Accordingly, based on the response of the respondents the researcher has ranked the existing response strategies by using the Likert scale method. Using the Likert scales is the popular methods of collecting data for the survey (Zikmund, 2003).

Finally, a Likert scale was used in this article which asked respondents to best describe which existing response strategies employed in their farmlands in advance as: 1 strongly agree, 2 agree, 3 neutral, 4 disagree and 5 strongly disagree. Therefore, the article analyzed only the five major existing women's response strategies to climate changes based on their rank results. 
Figure 2: Existing response methods used by women (N92)

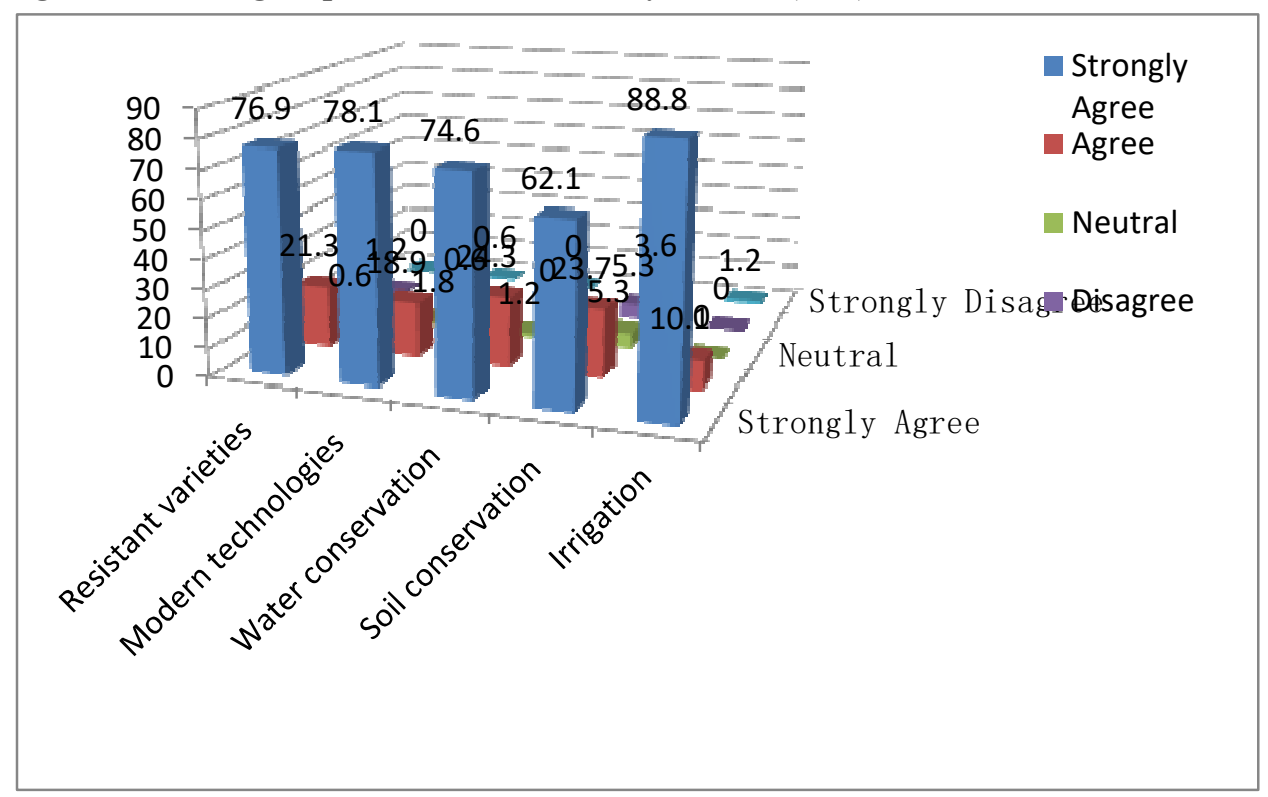

Source: Own survey, 2017

1. Use of Irrigation

As the above figure indicates that the majority respondents, $88.8 \%$ from both Kebelles reported that they used frequently in this type of response practice on their farmland. This was also consolidated by the focus group discussions and key informant interviews.

\section{Use of Modern Agricultural Technologies}

This refers to use of new agricultural technologies such as plant varieties and animal breeds resistant to drought and heat. From the above figure, results show that about 78.1\% respondents have strongly agreed. Accordingly, almost all respondents were using modern technology as response strategies to climate change.

\section{Use of Drought Resistant Varieties}

In confirming the use of drought-resistant varieties in both Kebelles, as stated in the above figure the majority number about $76.9 \%$ respondents were strongly agreed in using of drought-resistant varieties.

Furthermore, as the data obtained from focus group discussion women were used drought-resistant varieties in their farmland like Maize, Barley, Potatoes and different local cereals. But, there were different diseases which affected these different varieties. One participant in the focus group discussion consolidated the above finding by saying that:

"It well knows, during this drought period, we applied different drought resistant crops in our farm land to adapt changes in climate. However, there are several local diseases was an outbreak, which affected these crops. Thus, this led to crop failure in our Kebelle."

Thus, the use of drought resistant varieties as an response strategies are important for women as a source of income during drought time by selling these different drought resistant crops to the market.

\section{Water Conservation/Harvesting}

Shortage of water is directly affecting women because it is their responsibility to take care of the water needs. Thus, water harvesting methods, including water ponds, hand-dug wells and constructed water storage tanks connected to the roofs of houses are important for women to conserve water.

Thus, according to the above figure implied that $74.6 \%$ strongly agreed. The implication of this data is almost all women in both Kebelles were used, these varied water conservation techniques as response strategies to climate changes.

\section{Soil Conservation Practices}

Soil conservation practices, including terracing, mulching, contour plough and use of organic manner. Terracing is mainly done on the mountain slopes. In addition, mulching is done to maintain moisture in the soil by covering it with grass. As shown in the above Figure, about $62.1 \%$ respondents have strongly agreed in the participation of soil conservation practices. However, most respondents have applied frequently terracing (the traditional way). Thus, there is a problem regard to this, they can only use on certain soil types and are not constructed on fields with sandy soils.

\section{Determinants of Women's Response Strategies}

In general, women's decision behaviors to the different response strategies to climate change effects, especially in low-income countries, is influenced by a complex set of socioeconomic, demographic, technical, institutional 
and biophysical factors (Feder et. al, 1985).

To count the impact of various explanatory factors affecting women's adopt of response methods, a binary logistic regression model was used in this article. In the following sub-sections, the results of logistic regression analysis performed to identify determinants of women's adoption of response strategies in the study areas are presented below. The coefficients of logistic regression that tell us about the direction of effect of independent variables are presented below.

Response strategy dummy dependent variable $\mathrm{Y}=1$ if a respondent reported have adopted response methods to climate change; $Y=0$ if a respondent does not. The final model (based on equation 2) having 15 independent variables that fitted to the data are given by

$\operatorname{logit}(p)=\beta 0+\beta 1 X 1+\beta 2 X 2+\ldots+\beta 15 X 15$

Where $\beta 0$ is constant; $X 1$ is respondent age; $X 2$ is respondent education; $X 3$ is total family size; $X 4$ is access to training; $X 5$ is farm size; $X 6$ is farm experience; $X 7$ is saving money; $X 8$ is on farm income (in quintal); $X 9$ is access to credit service; $X 10$ is distance to the main market; $X 11$ is access to radio or mobile; $X 12$ is access to oxen plough; $X 13$ is livestock ownership in number, X14 is access to formal or informal group and $X 15$ access to decision-making.

The outcome in table 3 below presents logistic estimates of the determinants of women's response strategies to climate change. The probability of the model Wald chi-square $\left(\mathrm{X}^{2}(15)=143.373 \mathrm{df}=18\right.$, at $\mathrm{p}$-value 0.000$)$ less than the level of significant at 0.01 (i.e. $\mathrm{P}<0.001$ ) suggesting that there was a significant association between observed individual household variables related to adopting response strategies and model prediction. The $p$ value $=0.001$ implying a well-fitting model is significant at the $1 \%$ level, hence, our p-value is in the acceptable value signifying a good fit i.e., the model is accurate. The main coefficients showed that significantly effect at $95 \%$ and $90 \%$ confidence intervals. And also the strength of the model was tested using Cox and Snell 0.572 and Nagelkerke 0.769 suggesting that between $57.2 \%$ and $76.9 \%$ is explained by the set of variables used in the model and also correctly classified $87.0 \%$ of cases.

A logistic regression was performed to ascertain the effects of the 15 variables considered in the model, five were found to have a significant impact in determining adoption of response strategies to climate change and the finding is consistent with other findings. The logistic regression coefficients give the change in the log odds of the outcome of a one-unit increase in the predictor variable. Thus, analyses of specific statistically significant explanatory variables are discussed below;

Table 3 Odds ratio from binary logit model determinants to adopt response strategies

\begin{tabular}{|c|c|c|c|c|c|c|}
\hline Variables & Coef. $(\beta)$ & Std. Err. $(\beta)$ & P-value & Odds Ratios $=\operatorname{Exp}(\beta)$ & \multicolumn{2}{|c|}{ 95\% Conf. Interval } \\
\hline $\mathrm{AGE}$ & $0.151 * * *$ & 0.043 & 0.000 & 1.163 & 1.069 & 1.264 \\
\hline EDLEH(cat) & & & 0.571 & & & \\
\hline EDLEH(1) & 1.705 & 1.011 & 0.092 & 5.503 & 0.758 & 39.937 \\
\hline EDLEH(2) & 0.912 & 1.259 & 0.469 & 2.488 & 0.211 & 29.321 \\
\hline EDLEH(3) & 0.241 & 1.555 & 0.877 & 1.273 & 0.060 & 26.798 \\
\hline EDLEH(4) & 18.86970 & 40192.970 & 1.000 & 156589171.684 & 0.000 & \\
\hline FAMSZ & 0.088 & 0.171 & 0.608 & 1.091 & 0.781 & 1.525 \\
\hline ACCTRA & $6.509 * * *$ & 1.310 & 0.000 & 671.430 & 51.551 & 8745.123 \\
\hline FARMSZ & 0.371 & 0.755 & 0.624 & 1.449 & 0.330 & 6.364 \\
\hline FARMEXP & $0.095 * *$ & 0.047 & 0.045 & 1.099 & 1.002 & 1.206 \\
\hline SAVMONY & -0.886 & 0.669 & 0.185 & 0.412 & 0.111 & 1.530 \\
\hline ONFARMI & 0.015 & 0.121 & 0.903 & 1.015 & 0.800 & 1.287 \\
\hline ACCRDS & $1.774 * *$ & 0.704 & 0.012 & 5.896 & 1.483 & 23.438 \\
\hline DISMMAR & -0.195 & 0.152 & 0.200 & 0.823 & 0.610 & 1.109 \\
\hline ACCRMOB & $2.825 * * *$ & 0.927 & 0.002 & 16.866 & 2.743 & 103.709 \\
\hline ACCOXP & 0.761 & 0.881 & 0.388 & 2.141 & 0.381 & 12.042 \\
\hline LIVOWNP & 0.019 & 0.042 & 0.659 & 1.019 & 0.938 & 1.107 \\
\hline ACCFIG & 0.766 & 0.983 & 0.436 & 2.151 & 0.314 & 14.755 \\
\hline ACCDECM & -1.105 & 0.802 & 0.168 & 0.331 & 0.069 & 1.594 \\
\hline CONST & -10.736 & & 2.901 & 0.000 & -7.66 & -1.15 \\
\hline
\end{tabular}

Source: own survey, 2017

Note: $* * *$ significant at $1 \%$ level and $* *$ significant at $5 \%$ level respectively;

Observations $=92$

Wald chi2 $(15)=143.373$

Prob $>$ chi $2=0.000$

Log likelihood $=86.578$

Pseudo R2 = Cox and Snell 0.572; Nagelkerke $=0.769$ 
Age

The above table shows that the odds of adopted response strategies (versus not adopted response strategies) are 1.163 times greater for every one unit change in age and the other variables in the model kept constant. Thus, increasing age was associated with an increased likelihood of adopting response strategies.

Likewise, the coefficient of age has a significant and positive correlation with adopting of response strategies to climate change. This indicates a positive relationship between age and the possibility of adopting response methods to climate change. According to the results in table 3 above, one unit of change in the age of respondent significantly increases the probability of adopting response methods to climate change by a factor of 0.151 and significant at the $1 \%$ level (P-value $0.000 * * *$ ).

The reason for this result, older women are more experienced and knowledgeable about past climatic events which mean that they are able to use their past farming experience to outfit the current conditions. This finding is consistent with the FAO, (2005) noted that an adult woman with experience in farming activities was able to adopt different response methods to climate change than younger women with less experience. In addition, the same result was found by (Dolisca et al. 2006), have indicated that age has positive significance in influencing women's to adopt of response measures to climate change effects. Thus, the finding of this study has a consistency with the above findings.

\section{Access to training}

According to, the result of the above table shows that the odds of adopted response strategies are 671.430 times higher for having access to training compared to do not have access to training. Other factors remained constant. Thus, having access to training was associated with an increased likelihood of adopting response strategies.

Alike, the coefficient of this variable was found to be a key determinant factor in adopting response strategies to climate change in the two study areas. This indicates there was a positive relationship between access to training and the possibility of adopting response methods to climate change. Accordingly, having access to training significantly increases the probability of adopting response measures to climate change by a factor of 6.509 and significant at the $1 \%$ level (P value $0.000^{* * *}$ ). The possible reason, providing climate-related training for women is very important in developing the capacity to adapt climate changes. For instance, when women generated different training in relation to the mechanisms of response simply they can adopt several response strategies to climate change on their farmland. In addition, this result is similar with UNFPA, 2009; access to training is having a positive and significant relationship with women's response strategies to climate change.

\section{Farming experience in years}

As indicated in the above table the odds ratio of adopted response strategies (versus not adopted response strategies) is 1.099 times greater for every one unit change in years of farming experience. Thus, having enough experiences in farming was associated with an increased likelihood of adopting response strategies to climate change.

In regards to the coefficient of this variable, there was a significant and positive relationship found to exist between farming experience in years and adopting response methods to climate change. For instance, the probability of adopting response strategies would increase when the year of farming experience increases. Therefore, the probability coefficient of farming experience in the year was increase by a factor of 0.095 and significant at the $5 \%$ level ( $\mathrm{P}$ value $0.045^{* *}$ ) in the study areas. The possible reason is experienced women are likely to have more information and knowledge on changes in climatic conditions and crop and livestock management practices and other factors held constant.

The results of the article are consistent with those from Maddison (2007) and Nhemachena and Hassan (2007) which also found a positive relationship between years of farming experience and adopt of response measures to climate change. Thus, the researcher concluded that women with greater farming experience are likely to be more aware of past climate events and better judge how to adapt their farming to extreme weather events.

\section{Access to credit service}

As pointed out in the above table, the odds ratio of adopted response strategies is 5.896 times higher for having access to credit service opposed to do not have access to credit service. Thus, having access to credit service was associated with an increased likelihood of adopting response strategies to climate change.

Furthermore, the coefficient of this variable has a significant and positive relationship with adopting response measures and found that this was a very important factor in adopting response strategies to climate change effects. Accordingly, as the results indicate in table 3 above, having access to credit service significantly increases the probability of adopting response methods to climate change by a factor of 1.774 and significant at the $5 \%$ level (p-value $0.012^{* *}$ ). Other factors remained constant. The reason behind this access to credit is 
assumed to be an important factor to introduce new technology, to buy modern crop, fertilizer, oxen etc.

This result was in agreement with the findings of Nhemachena and Hassan (2007), who stated that; women's access to credit services increases their ability to meet transaction costs associated with various adaptive strategies they might want to take like obtaining fertilizers, insecticides which may increase yields and enhance productivity. Additionally, Gbetibouo (2009) suggested that the major factor restraining farmers' response to climate change is inadequate access to credit.

\section{Access to radio or mobile}

This is another key determinant factor for adopting response methods to climate change. As depicts in the above table the odds ratio of adopted response strategies is 16.866 times higher for having access to radio or mobile unlike to do not have access to radio or mobile. Thus, having access to radio or mobile has associated with an increased likelihood of adopting response strategies to climate change.

Moreover, in the study areas, access to a radio or a mobile phone was statistically significant and positively correlated with adopting of response techniques to climate change. This indicates that with access to radio or mobile, the probability of women adopting response methods in their farming land increases by a factor of 2.825 compared to these do not have access to radio or mobile and this was significant at the $1 \%$ level (p-value $0.002^{* * *}$. Other factors held constant. Because radio or mobile are the best electronic materials for women to get information about what is going on in regards to how to adopt climate change and to transmit meteorological information simply to women about the change in temperature and rainfall. Thus, this is important for women to take necessary measures before and after the change in climate on their farm land in the study areas.

This result is consistent with the findings of UNFPA, (2009) that access to radio or mobile would have important to get early warning and climate relate information which help women to take appropriate actions in a timely manner depending on expected weather conditions. Additionally, the result of Nhemachena and Hassan (2007) come across that access to information about climate change forecasting, response options and other agriculture activities remain important factors determining the use of various climate change response methods.

\section{SUMMARY AND CONCLUSION}

The article intends to analyze the determinants of women's strategies to climate change. In order to achieve this general purpose, both quantitative and qualitative data have been used. The article predominantly depends upon survey data, and accordingly data have been collected from women through questionnaire survey in the study areas.

The article reveals that there are different existing response strategies that have been adopted by women in the study areas. These response strategies of climate changes that have used are drought resistant varieties, use of modern technologies, water conservation, soil conservation practices and irrigation. Therefore, the implication of this result ensured that these different response measures have created an opportunity for women to adapt climate change in a better way and minimized the severity of drought in their areas.

Another important issue that this article addressed is assessing the key determinants of women adopting of response strategies to climate changes. To this end, there are 15 independent variables are considered as factors to determine the women's response methods to climate changes. In relation to this, the result of the binary logistic regression shows that from these 15 independent variables this article found that only 5 variables have a positive relationship and statistically significant. These are age, access to training, farming experience, access to credit service and access to radio or mobile of the women; which are significant at the $1 \%$ level, $1 \%$ level, $5 \%$ level, 5\%level and 1\% level respectively. Therefore, the implication of this data shows that these major independent variables have an influence on the decision of women to use different response methods on their farmland to adapt climate change.

\section{RECOMMENDATION AND POLICY IMPLICATION}

In response to the finding of this article, the following recommendations and policy implications are given below:

- The result of this article shows that there are different existing response strategies employed by women in the study areas. However, the adopters believed that the response measures they employed are not enough to reduce the impact of current climate change. Hence, designing policies with the aim of improving these mechanisms will improve farm level response strategies the climate changes. Accordingly, the government should revisit and reform policies regarding the issues so that they become important tools to enhance individual response strategies to climate changes.

- The result of binary logistic model highlights that age, access to training, farming experience, access to credit service and access to radio or mobile are positively and significantly related to women adopting response strategies to climate change. Therefore, the government should design, revisit and reform policies in improving these factors and also non-governmental organizations should be the focus on improving these factors via providing climate-related training and credit service for women in the study 
area. In addition, marking and modelling such women is important in promoting, adopting response methods to other women who do not have such experience and are not yet adopting response measures to adapt changing climatic conditions.

\section{Reference}

ACCRA, (2011). Preparing for the future, Understanding the influence of developmentinterventions on adaptive capacity at the local level in Ethiopia, 0/3/rr-accra-ethiopia development-adaptive-capacity-report-271011en.pdf

Adger, W.N. S., Agrawala, M.M.Q., Mirza, C., Conde, K. O’Brien, J., Pulhin, R., Pulwarty, B., Smit and Takahashi, K. (2007). Assessment of Response practices, options, constraints and capacity. Climate Change 2007: Impacts, Response and Vulnerability. Contribution of Working Group II to the Fourth Assessment Report of the Intergovernmental Panel on Climate Change, Cambridge University Press, Cambridge, UK, 717-743.

Anne, T. (2009). Assessing Vulnerability and Adaptive Capacity to Climate Risks: Method for Investigation at Local and National Levels. SOCIAL DEVELOPMENT WORKING PAPERS Paper No. 116/, Social Development The World Bank 1818 H Street, NW Washington, DC 20433.

Blackden, C.M., and Wodon, Q. (2006). Gender, time use and poverty in sub-Saharan Africa, World Bank Working Papers 73. World Bank: Washington DC. USA.

Casley, and Kumar, 1998. The collection, Analysis and use of Monitoring and Evaluation Data. Baltimore, MD: The John Hopkins University Press

Central Statistical Authority of Ethiopia (2001). Agricultural Sample Survey. Report on Area and Production Afar Region.

Census, (2007). Afar Region Archived November 14, 2010, at the Wayback Machine., Tables 2.1, 3.4

CGD, 2012. Mapping the impacts of climate change vulnerability. Retrieved 10 February2012fromhttp://www.cgdev.org/section/topics/climate_change/mapping_the_impacts of climate change

Cutter, S.L. (1995). The forgotten casualties: women, children, and environmental change. Global Environ. Chang 5, 181-194.

Dankelman, I. (2002). Climate change: learning from gender analysis and women's experiences of organizing for sustainable development. Gender and Development, 10, 21-29.

Denton, F. (2002). Climate change vulnerability, impacts, and Response: why does gender matter? Gender and Development, 10, 10-20.

Dinku T, Asefa K, Hilemariam K, Grimes D, and Connor S, 2011. Improving availability, access and use of climate information, WMO 60 (2).

Dolisca, F., Carter, R.D., McDaniel, J.M., Shannon, D.A., and olly, C.M. (2006). Factor influencing farmers' participation in forestry management programs: A case study from Haiti. Forest Ecology and management (236), 324-331.

FAO, (2005). Special Event on Impact of Climate Change, Pests and Diseases on Food Security and Poverty Reduction, Background Document for 31st Session of IDS WORKING PAPER the Committee on World Food Security. Rome. 23-26 May 2005

Feder, G., Just, R., and Zilberman, D. (1985). Adoption of agricultural innovations in developing countries: A Survey of Economic Development and Cultural Change 33 (2): 255-98.

Gbetibouo, G. A. (2009). Understating Farmers' Perceptions and Response to Climate Change and Variability: The Case of the Limpopo Basin. IFPRI, Discussion Paper Washington, D.C., IFPRI.

Green, W.H. (2003). Econometric Analysis.5th edition Pearson Education, Inc., Upper Saddle River, New Jersey

Gujarati, D. (2003). Basic Econometrics.3 ${ }^{\text {rd }}$ edition Mc Graw-Hill, Inc: New York.

Hailu E.K. (2008). Baseline Survey of 55 Weredas of PCDP Phase II, Part I Archived July 20, 2011, at the Wayback Machine. (Addis Ababa: August 2008),

Kothari, C. R. (2004). Research Methodology: Methods and Techniques. New Age InternationalNew Delhi, India

Maddison, D. (2007). The perception of an Response to climate change in Africa, World Bank Policy Research Working Paper, Wold Bank, Washington DC,

Mbwambo, J. S., (2007). Agro biodiversity and food security among smallholder famers in Uluguru Mountain, Tanzania, Sokoine University of Agriculture, Morogoro. pp 18.

Robert Mepham, R. H. Hughes, and J. S. Hughes, (1992). A directory of African wetlands, (Cambridge: IUCN, UNEP and WCMC, 1992), p. 166

Nhemachena, C., and Hassan, R. (2007). Micro-level analysis of farmers' adaption to climate change in Southern Africa, Intl. Food Policy Res. Inst., Washington, DC, 
Ulrike, (2006). Linguistic awareness in multilingual: English as a third language. Edinburgh, UK: Edinburgh University Press.

UNFPA. (2009). Climate Change Connections; Women at the Forefront. Response and Mitigation Nairobi, Kenya

Yamane, T. (1967). Statistics: An Introductory Analysis, $2^{\text {nd }}$ Ed, New York: Harper and Row.

Yesuf, M., Falco, D. S., Deressa, T., Ringler, C., \& Kohlin, G. (2008). The Impact of Climate Change and Response on Food Production in Low-Income Countries. Ethiopia Development Research Institute. International Food Policy Research Institute. Discussion Paper No: 828, Washington D.C. IFP.

Yohannes G., and Mebratu, K. (2009). Local innovation in climate-change Response by Ethiopian pastoralists. PROLINNOVA Ethiopia and Pastoralist for Ethiopia (PFE) Addis Ababa.

Zikmund, W.G. (2003). Sample designs and sampling procedures, Business research methods, 7, pp.368400.ed Methods Research, 3(2), pp.95-108.

\section{Appendices}

Appendix- Tests of Multicollinearity (VIF and CC)

Table 1: Co linearity statistics Variance inflation factor (VIF) for continuous variables

\begin{tabular}{|l|l|l|}
\hline Variable & Tolerance & VIF \\
\hline Age of household head (Age) & 0.763 & 1.311 \\
\hline Family Size (FAMSI) & 0.890 & 1.124 \\
\hline Farm size (FARMSZ) & 0.765 & 1.308 \\
\hline Farming experience (FARMEXP) & 0.788 & 1.269 \\
\hline On farm income (ONFARMI) & 0.915 & 1.093 \\
\hline Distance to main market (DISMMAR) & 0.886 & 1.128 \\
\hline Livestock ownership (LIVOWNP) & 0.853 & 1.172 \\
\hline
\end{tabular}

Source: Own survey, 2017

Table 2: Contingency Coefficients (CC) for discrete variables

\begin{tabular}{|c|c|c|c|c|c|c|c|c|}
\hline & EDLEH & ACCRMOB & ACCSTRA & SAVMONY & ACCRDS & ACCOXPC & ACCFIG & ACCDECM \\
\hline \multicolumn{9}{|l|}{ EDLEH } \\
\hline ACCRMOB & .115 & & & & & & & \\
\hline ACCSTRA & .130 & .309 & & & & & & \\
\hline SAVMONY & .252 & .186 & .285 & & & & & \\
\hline ACCRDS & .165 & .087 & .305 & .304 & & & & \\
\hline ACCOXPC & .155 & .279 & .238 & .060 & .141 & & & \\
\hline ACCFIG & .165 & .014 & .131 & .112 & .097 & .049 & & \\
\hline ACCDECM & .244 & .134 & .250 & .248 & .089 & .105 & .357 & \\
\hline
\end{tabular}

Source: Own survey, 2017 